\title{
Ultrastructural Studies of Sporulation in Bacillus sphaericus
}

\author{
STANLEY C. HOLT, ${ }^{*}$ J. J. GAUTHIER, ${ }^{1}$ AND D. J. TIPPER \\ Department of Microbiology, University of Massachusetts, Amherst, Massachusetts 01002, ${ }^{*}$ and University of \\ Massachusetts Medical School, Worcester, Massachusetts 01600
}

Received for publication 23 December 1974

\begin{abstract}
Spore septum formation in Bacillus sphaericus 9602 occurs $2 \mathrm{~h}$ after the end of exponential growth at one end of the vegetative cell, which retains a uniform diameter. The apparently rigid spore septum contains an inner cell wall layer which disappears when the sporulation septum "bulges" into the mother cell cytoplasm. This process occurs simultaneously with terminal swelling at the end of the cell containing the spore septum. It is suggested that the inner cell wall layer is peptidoglycan and that its dissolution and the terminal swelling are consequences of a localized autolysis. Engulfment of the forespore by membrane proliferation results in the production of a forespore surrounded by two flexible, closely apposed membranes. These membranes appear to become more rigid as a peptidoglycan-like layer appears between them, concomitant with the condensation of the forespore nucleoid into a crescent-shaped structure. After nuclear condensation, visible development of distinct cortex, primordial cell wall, and spore coat layers begin, and the forespore cytoplasm assumes an appearance similar to that of a refractile spore. The spore coats consist of an amorphous inner layer, a lamellar midlayer, and a structured outer layer. As cortex synthesis and spore coat assembly continue, exosporium development commences close to that portion of the mother cell plasma membrane which surrounds the forespore. The exosporium is lamellar and in tangential section is seen to have a hexagonal arrangement of subunits. The timing of these morphological events has the expected correlation with the appearance of unique enzyme activities required for cortex synthesis.
\end{abstract}

Bacillus sphaericus is an aerobic, spore-forming gram-variable bacillus, which differs from the extensively studied aerobic species such as Bacillus subtilis, Bacillus cereus, and Bacillus megaterium in several characteristics. For example, by phase contrast microscopy its sporangium appears swollen around its forespore and the spore appears to be spherical. Almost all aerobic sporogenic bacilli and Clostridia have a type $\mathrm{A} 1 \gamma$ (19) vegetative cell wall peptidoglycan in which tetrapeptides containing meso- $\alpha, \epsilon-$ diaminopimelic acid are cross-linked directly through D-alanine residues (reviewed in references 19,22$)$. Similar A1 $\gamma$ structures are found in the peptide units of the spore cortical peptidoglycan of these organisms (26) as well as in $B$. sphaericus (D. J. Tipper, Bacteriol. Proc., p. 24, 1969). In contrast to the spore peptidoglycan, the vegetative cell wall peptidoglycan of $B$. sphaericus is a type $A 3 \alpha(19)$ structure in which $\mathrm{L}$-lysine residues are cross-linked through D-alanyl-D-isoasparaginyl residues (13). Sporulating

' Present address: Dept. of Biology, University of Alabama, Birmingham, Ala. 35294. and stationary-phase cells of $B$. sphaericus tend to stain gram-negative, whereas the cell wall composition of the vegetative cell is clearly of the gram-positive type (compare 22). The presence of an unusually low content of peptidoglycan $(20 \%)$ may contribute to the relative ease with which cells are decolorized in the gramstaining procedure. Further, the cell wall is unusual (among aerobic spore formers) in lacking teichoic acid and in that more than $50 \%$ of its mass is made up of an external layer of tetragonally arranged polypeptide subunits referred to as the T-layer by Brinton (compare Brinton, McNary, and Carnahan, Bacteriol. Proc., p. 48, 1969). The remaining 15 to $20 \%$ of the wall consists mainly of an as yet unidentified polysaccharide (D. J. Tipper, unpublished observations). The walls of Bacillus polymyxa appear to have a composition similar to that of $B$. sphaericus. The cell wall layers of $B$. poly$m y x a$, as seen in thin section after uranyl acetate staining, consist of an outer, densely staining $\mathrm{T}$-layer protein, an intervening unstained polysaccharide layer, and an internal, densely 
staining peptidoglycan layer (15). The profiles of $B$. sphaericus cell walls have been similarly interpreted (see below).

$B$. sphaericus (and the apparently closely related species, Bacillus pasteuriae, compare reference 19) is in a unique class with respect to cell wall peptidoglycan structure and this has been exploited in biochemical studies of the synthesis of cortex peptidoglycan during sporulation (24). These studies have been aided by the relatively high efficiency and synchrony of sporulation in $B$. sphaericus strain 9602 , and the ease with which these parameters can be quantitated by phase contrast microscope observation of sporangial terminal swelling.

There have been no reported electron microscope studies of sporulation in $B$. sphaericus apart from some freeze-etching studies of a strain apparently unrelated to strain 9602 (11). The investigations reported here were initiated to provide correlations between the morphological appearance of spore components, in particular those containing peptidoglycan, and the biochemical events involved in spore peptidoglycan synthesis. In addition to the close correlation between morphology and biochemistry, the thin sections also illustrate some unique aspects of sporulation in this organism, the most striking of which is the fact that the initial spore septum apparently contains peptidoglycan across its entire width.

\section{MATERIALS AND METHODS}

Growth and sporulation conditions. B. sphaericus 9602 was grown in BS broth plus spore salts at $33 \mathrm{C}$ with vigorous aeration as previously described (13). BS broth contains, per liter, the following Difco ingredients: antibiotic medium number $3,7.5 \mathrm{~g}$; peptone, $2 \mathrm{~g}$; and beef extract, $3 \mathrm{~g}$. Refrigerated spore stocks of $B$. sphaericus $\left(5 \times 10^{8}\right.$ spores $\left./ \mathrm{ml}, 0.1 \mathrm{ml}\right)$ were heat-shocked for $30 \mathrm{~min}$ at $80 \mathrm{C}$ and used to inoculate $20 \mathrm{ml}$ of BS broth and salts in a $250-\mathrm{ml}$ Erlenmeyer flask equipped with a side arm suitable for insertion in a Klett colorimeter (initial reading $=0$ to 2). The flask was shaken at $33 \mathrm{C}$ in a G86 water bath orbital shaker (New Brunswick Scientific) at 250 rpm. At mid-exponential growth (ca. 6 h) (Klett reading $=30$, red filter), $1 \mathrm{ml}$ of the culture was used to inoculate a second Erlenmeyer flask containing 20 $\mathrm{ml}$ of BS broth plus salts which had been prewarmed to $33 \mathrm{C}$. The flask was again incubated at $33 \mathrm{C}$ on an orbital shaker until mid-exponential growth was attained, at which time $5 \mathrm{ml}$ of this culture was used to inoculate $200 \mathrm{ml}$ of prewarmed BS broth and salts in a fluted-bottom, 2,000-ml Erlenmeyer flask which was shaken at $250 \mathrm{rpm}$ in a G25 shaker-incubator (New Brunswick Scientific) at $33 \mathrm{C}$. This culture was used for all biochemical and cytological observations.

Preparation of samples for electron microscopy. Samples $(5 \mathrm{ml})$ of the $200-\mathrm{ml}$ culture were removed at
30 -min intervals and centrifuged (5 min, 18,000 rpm) and the cell pellets were suspended in freshly prepared $2 \%$ glutaraldehyde in $0.1 \mathrm{M} \mathrm{KPO}_{4}, \mathrm{pH}$ 7.3. The samples were stored at $4 \mathrm{C}$ until prepared for final fixation. Prior to postfixation in osmium, the samples

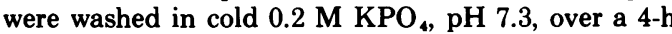
period. The cells were placed into $1 \%$ (wt/vol) $\mathrm{OsO}_{4}$ (in $0.2 \mathrm{M} \mathrm{KPO}$, $\mathrm{pH} \mathrm{7.3)}$ and fixed for $12 \mathrm{~h}$ at room temperature $(20 \mathrm{C})$. The samples were shaken intermittently during the first hour in $\mathrm{OsO}_{4}$. After osmium fixation, the cells were washed one time in cold distilled water and centrifuged at low speed $(5 \mathrm{~min}$, $5000 \mathrm{rpm}$ ) and the resulting pellets were placed in $2 \%$ Noble agar (in distilled water), cut into blocks $1 \mathrm{~mm}$ square and poststained in $0.5 \%$ (wt/vol) aqueous uranyl acetate for $2 \mathrm{~h}$. The blocks were rinsed one time in cold distilled water, dehydrated through ethanol or acetone and embedded in Epon 812 or Spurr's embedding plastic.

All samples were cut with a diamond knife, and the thin-sections were stained with $7.5 \%(\mathrm{wt} / \mathrm{vol})$ aqueous uranyl acetate and lead citrate and examined in a Philips EM 200 electron microscope operating at 60 $\mathrm{kV}$. All thin-sections were stained at the same time by employing a multi-staining apparatus.

\section{RESULTS}

Microscopic observations of synchrony. (i). The kinetics and degree of synchrony of sporulation in $B$. sphaericus, as judged by phase contrast microscopy, are critically dependent on several interrelated factors. These include the number of prior generations of balanced (exponential) vegetative growth, the medium composition, and the efficiency of aeration of the culture. The cultures used for electron microscopy had reasonably good synchrony (Fig. 1 and Table 1). The doubling time as measured by Klett and cell numbers in vegetative growth is $35 \mathrm{~min}$ at $33 \mathrm{C}$ (Fig. 1) and is followed by a period of residual cell division (Klett doubling time $80 \mathrm{~min}$; Fig. 1). This cell division continues until shortly before terminal swelling becomes microscopically apparent, and involves both a doubling in cell number and a halving of cell volume and length (G. G. Khachatourians and D. J. Tipper, unpublished observations). The break point in the absorbancy profile (Fig. 1) is used to define the time of initiation of sporulation, that is, $\mathrm{T}_{0}$. At $\mathrm{T}$ $=2 \mathrm{~h}$, subterminal sporulation septa are occasionally seen in phase contrast microscopy (see Fig. 7a, b), although they become more obvious as terminal swelling ensues shortly thereafter $(\mathrm{T}=2.4 \mathrm{~h})$. Swelling is complete by 3.2 $\mathrm{h}$, at which time forespore engulfment is also complete (Table 1). The forespores do not become clearly delineated in the phase microscope until about $T=4 \mathrm{~h}$. However, during the period from $\mathrm{T}=3 \mathrm{~h}$ to $\mathrm{T}=4 \mathrm{~h}$, electron micro- 


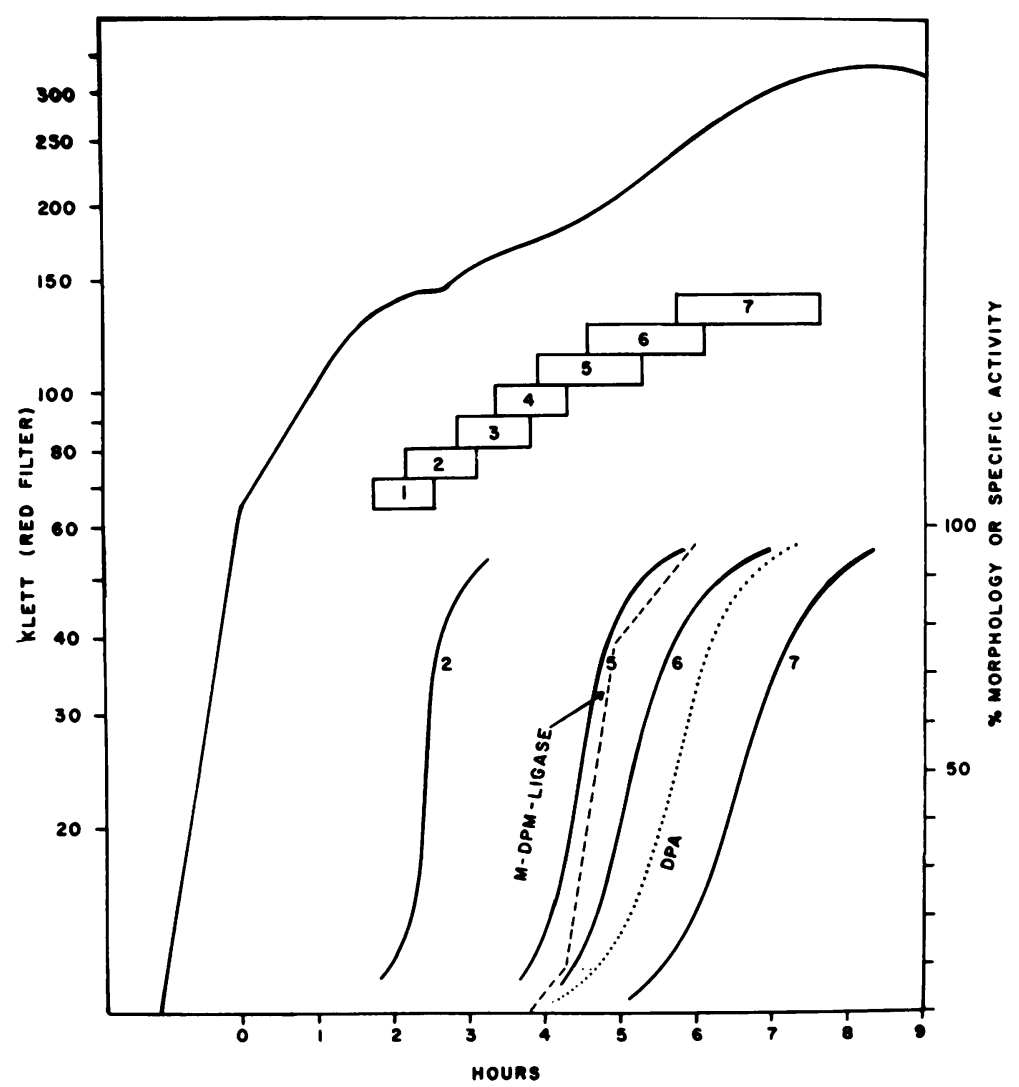

Fig. 1. Correlation of phase microscopic, ultrastructural and biochemical observations during sporulation in B. sphaericus 9602. The upper curve shows the absorbancy measured on a Klett colorimeter with a red filter. Time in sporulation is measured from the abrupt break in the absorbancy curve $(T=0 h)$. Bars numbered 1 to 7 indicate the time periods over which 10 to $90 \%$ of the cells exhibit particular morphological characteristics listed by the same numbers in Table 1. Bars 2, 5, 6, 7 are phase microscope observations and are, respectively: initiation of terminal swelling, appearance of visible forespores within the swollen sporangium, acquirement of semi-refractility by the forespores, and acquirement of full phase brightness by the forespores. The curves representing the percent of cells exhibiting these morphologies are solid lines identified by the appropriate number. The dashed curve indicates the percent of maximal mesodiaminopimelate ligase activity in the cells, and the dotted curve represents the percentage of maximal diplicolinate accumulation by the cells (previously published, 24).

graphs show the initiation of primordial cell wall (PCW) and midcoat assembly (see below) as well as two marked changes in the appearance of the forespore cytoplasm (Table 1). Visible refractility of the forespores is acquired at $\mathrm{T}=5 \mathrm{~h}$ with coat and cortex development continuing as well as the initiation of exosporium development. As the process of sporulation nears completion $(\mathrm{T}=6.5 \mathrm{~h})$ and phase brightness approaches a maximum, the exosporium envelops the spore. In $B$. sphaericus, which has relatively weak autolytic systems during both vegetative growth and sporulation (D. J. Tipper, unpublished observations), the subsequent release of free spores is slow, and is complete only by $\mathrm{T}=16 \mathrm{~h}$.

(ii) Electron microscope observations: veg- etative cell wall, vegetative septation, and cell separation. Both Nomarski interference and phase contrast microscopy of vegetative cells show featureless dividing rods with a length to width ratio in newly divided cells of 4 to 6 (Fig. 2). In thin sections of these vegetative cells, the wall is clearly seen to have a layered structure (Fig. 3 and 4 ). The densely staining outer layer makes up approximately $50 \%$ of the wall thickness and is largely composed of structural protein, comprising the " $T$ " layer seen in negatively stained preparations (compare reference 15 and Discussion). Underlying this outer layer are two lighter-staining layers separated by a thin, densely staining layer, the latter presumed to be peptidoglycan (see Discussion).

The initial invaginations of vegetative septa 
TABLE 1. Correlation of phase contrast microscope and ultrastructural observations

\begin{tabular}{|c|c|c|c|c|c|}
\hline \multicolumn{3}{|c|}{ Time $^{a}(\mathrm{~h})$} & \multirow{2}{*}{$\begin{array}{l}\text { Marker } \\
\text { (Fig. 1) }\end{array}$} & \multirow{2}{*}{ Phase contrast observations } & \multirow{2}{*}{ Ultrastructure observations } \\
\hline $10 \%$ & 50\% & $90 \%$ & & & \\
\hline & $0-2$ & & & $\begin{array}{l}\text { Residual vegetative cell divisions } \\
\text { producing shorter, highly mo- } \\
\text { bile cells }\end{array}$ & Vegetative cells \\
\hline 1.7 & 2.0 & 2.4 & 1 & Some terminal septa visible & Spore septum formation \\
\hline 2.1 & 2.5 & 3.1 & 2 & Terminal swelling begins & Swelling, beginning of engulfment \\
\hline 2.8 & 3.2 & 3.7 & 3 & Fully swollen & $\begin{array}{l}\text { Completion of engulfment; "prune-form" } \\
\text { forespore }\end{array}$ \\
\hline 3.4 & 3.7 & 4.2 & 4 & Fully swollen & $\begin{array}{l}\text { Rounded forespore with crescent-shaped } \\
\text { condensed nucleoid }\end{array}$ \\
\hline 3.8 & 4.2 & 5.2 & 5 & Forespores visible & $\begin{array}{l}\text { Spore-type cytoplasm; early midcoat and } \\
\text { primordial cell wall development }\end{array}$ \\
\hline 4.5 & 5.0 & 6.0 & 6 & Forespores become semi-refractile & $\begin{array}{l}\text { Lamellar midcoat; start of cortex, outer } \\
\text { coat, and exosporium development }\end{array}$ \\
\hline 5.8 & 6.5 & 7.5 & 7 & Phase bright spores & $\begin{array}{l}\text { Completion of cortex, coat and exo- } \\
\text { sporium development }\end{array}$ \\
\hline & $>10$ & & & Free spores & Free spores \\
\hline
\end{tabular}

a The time periods for 10 to $90 \%$ of the cells to exhibit the indicated morphologies are those indicated by the numbered bars in Fig. 1. Cells begin to clump at about $\mathrm{T}=2.5 \mathrm{~h}$ and remain in clumps until sporangial lysis ensues.

${ }^{\circ}$ Percentage of cells exhibiting morphological changes.

in $B$. sphaericus comprise the inner light layer and the peptidoglycan layer but not the outer light or protein layers (Fig. 3). The cross wall is completed without any narrowing or pinching of the cell at the division point and initially contains a single inner dense layer separating the two new daughter cells (Fig. 4).

Separation of the cells is initiated by separation of two dense layers, presumably by insertion of outer light layer material between them. Separation of the dense layers has started in the cross wall of the cell shown in Fig. 4 and is complete in that shown in Fig. 5. As the poles of the daughter cells separate, they assume the roughly hemispherical shape of mature vegetative cell ends (Fig. 6). The outer protein layer envelops the entire outer surface of the separating daughter cells, but does not enter the maturing cross wall.

Formation of the sporulation septum. Since sporulation in B. sphaericus is a highly synchronous process, the probability of confusing vegetative septa with sporulation septa in samples taken from cells at the appropriate stage in sporulation (approximately $2 \mathrm{~h}$ after the end of vegetative growth) is extremely low, although postexponential vegetative cell division continues until $\mathrm{T}=1.6 \mathrm{~h}$. Moreover, sporulation septa can be easily differentiated by their terminal location.

Evidence of a terminal septum can be seen at $\mathrm{T}=2 \mathrm{~h}$ in some of the unswollen cells in both phase contrast and Nomarski micrographs (Fig. $7 a$ and b) (compare reference 7). Surprisingly, in thin sections taken at this time, these sporulation septa look essentially identical to early vegetative septa (compare Fig. 4), containing inner light layers symmetrically divided by a single dense peptidoglycan layer contiguous with that of the mother cell wall (Fig. 8). The invaginating spore septum is associated with large mesosomes (Fig. 8). The spore septum continues to grow into the center of the cell (Fig. $9 a$ and $b$ ) until the mother cell and the putative forespore are separated by a planar and apparently rigid cross wall (Fig. 10a and c). This is also shown in a section through the outer part of a sporulation septum in Fig. 10b. Cells from a culture in which $90 \%$ of the cells are swollen ( $\mathrm{T}$ $=3.2 \mathrm{~h}$ ) are seen in Fig. 11. The dimples visible at some of the swollen termini probably represent nascent engulfed forespores (7; see below).

Simultaneously with the initiation of swelling of the mother cell, the central region of the initially planar spore septum begins to bulge into the mother cell, leaving two annular stubs 

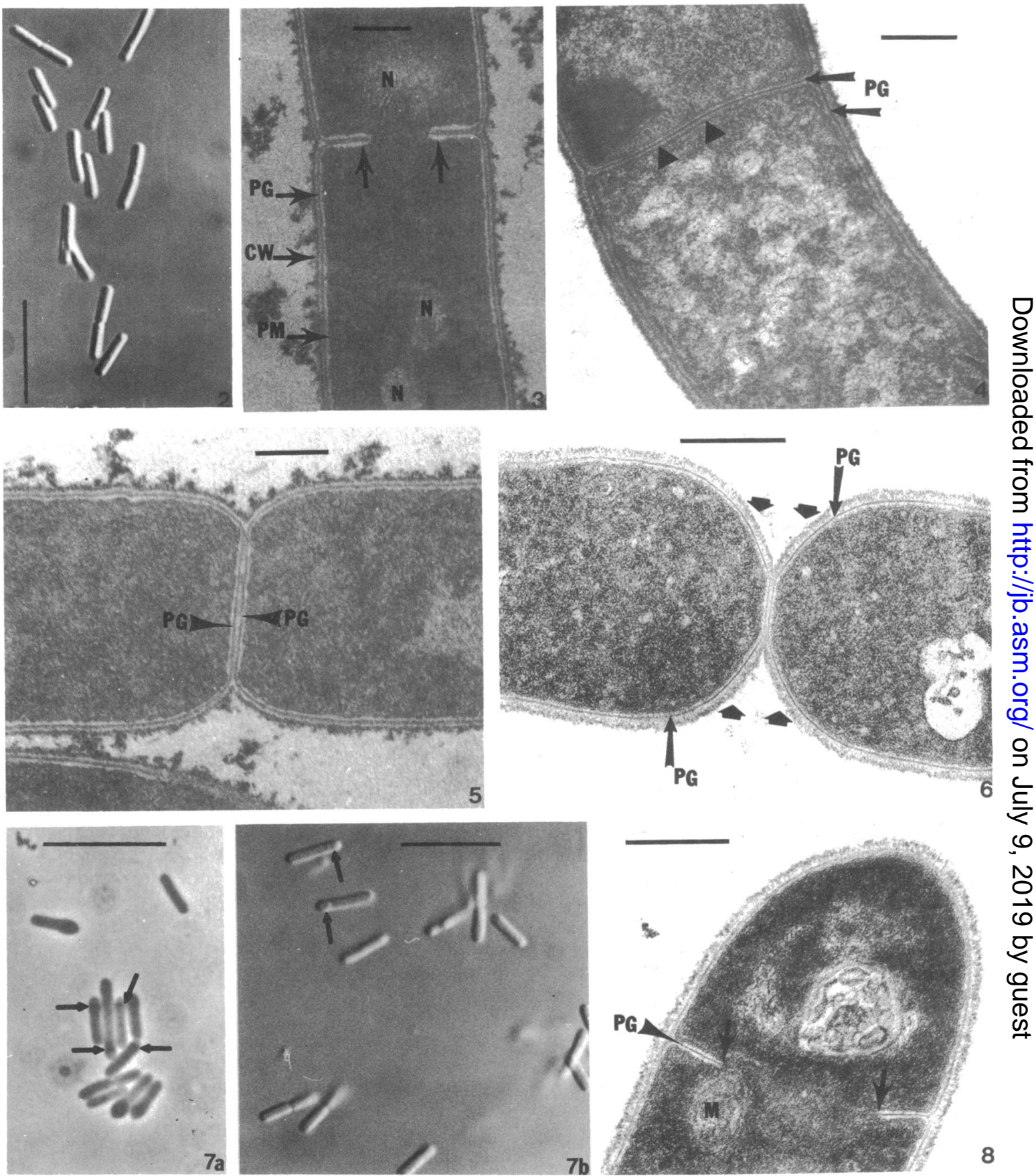

6

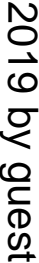

Fig. 2. Vegetative cells of B. sphaericus 9602. Nomarski interference contrast. Bar $=10 \mu \mathrm{m}$.

FIG. 3. Vegetative cell of $B$. sphaericus 9602 showing an invaginating cross wall and septum (arrows). The cell wall $(C W)$ is composed of an inner peptidoglycan layer $(P G)$ which encloses the plasma membrane $(P M)$ and is separated from an outer protein layer by an unstained layer. $N$, nuclear region; bar $=0.25 \mu \mathrm{m}$.

Fig. 4. Vegetative cell of $B$. sphaericus 9602 with a completed vegetative cross wall (arrow heads) containing a single peptidoglycan layer $(P G)$. Bar $=0.25 \mu \mathrm{m}$.

Fig. 5. A vegetative cross wall of B. sphaericus 9602 showing separation of two distinct peptidoglycan layers $(P G)$. Note the clear electron transparent zone in which the peptidoglycan layers sit, and their continuity with the cell wall peptidoglycan. Bar $=0.25 \mu \mathrm{m}$. 
at the septum's periphery. The material in this apparently less rigid central region of the spore septum now stains more darkly (Fig. 12a and b). Convoluted, mesosome-like continuations of apposed membranes resembling this region of the spore septum are frequently seen at the juncture of the rigid stubs and the plastic central section of the spore septum (Fig. 12a). This material probably represents the first stage of membrane proliferation involved in engulfment. In sections of cells taken at $\mathrm{T}=2.2 \mathrm{~h}$ (Fig. 13a, b, and c) when $20 \%$ of the cells are already visibly swollen at the terminus containing the spore septum, it can be seen that engulfment of the putative forespore has commenced and that initiation of engulfment does not occur simultaneously at all points on the periphery of the spore septum. In most of these sections, one end of the spore septum remains attached to one of the rigid stubs from the original spore septum. The other end of the sporulation septum is no longer attached at its stub. Mesosome-like structures are sometimes visible at the advancing edges of the membrane surrounding the developing forespore during engulfment (Fig. 14, 15). Eventually, at $\mathrm{T}=3$ $h$, when swelling is complete, the engulfment process approaches completion (Fig. 16a, b, c, $\mathrm{d}$, and e) and the annular invaginations of the mother cell wall, which marked the original septum site, gradually disappear. In rare instances when cell sections are examined at later times, the annular stub is seen adjacent to the mid-points of the maturing spore.

Also apparent at $\mathrm{T}=3 \mathrm{~h}$ is the large amount of membranous mesosome-like material associated with the final stages of engulfment (Fig. $16 \mathrm{a}, \mathrm{b}, \mathrm{c})$. This membranous material migrates toward the terminus of the cell (Fig. 16d, e) and finally, at about $\mathrm{T}=3.5 \mathrm{~h}$, a forespore is produced (Fig. 17a, and b) leaving a large terminal, mesosome-like structure in the mother cell (Fig. 17a). The nascent "pruneform" forespore appears to be plastic and is still surrounded by two closely approximated membranes with little visible intervening material. The forespore cytoplasm (Fig. 17b) has visible polysomes and a dispersed nucleoid, resembling that of a vegetative cell. Within $30 \mathrm{~min}, \mathrm{~T}=3.5$ h, the nucleoid starts to condense (Fig. 18, $\mathrm{T}=$ $4 \mathrm{~h}$ ), and the forespore becomes more symmetrical as a thin dark band appears symmetrically between its inner and outer membranes. The nucleoid rapidly becomes crescent-shaped and fibrous (Fig. 19, $\mathrm{T}=4 \mathrm{~h}$ ) and the material between the inner and outer forespore membrane now resembles a normal, rigid, vegetative septum with a faint line of peptidoglycan layer in its center.

The first stage of spore coat assembly also appears at $\mathrm{T}=4 \mathrm{~h}$ as a diffuse, unstructured line of higher density surrounding the outer forespore membrane (Fig. 19a). At $\mathrm{T}=4 \mathrm{~h}$, the forespore cytoplasm changes and resembles that of a mature refractile spore with a diffuse nucleoid and large dark granules which may be condensed polysomes (Fig. 20). All of the prior ultrastructural changes subsequent to the completion of swelling cause little change in the appearance of sporulating cells as revealed by phase contrast microscopy. However, with the increased contrast in the swollen end of the mother cell, the presence of prerefractile forespores is now visible (Table 1). At this time a darker layer can be distinguished immediately adjacent to the exterior of the inner forespore membrane. This dark layer, variously referred to as cortical membrane (25), germ cell wall (14), and primordial cell wall (5), and here referred to as primordial cell wall (PCW), is presumably vegetative-type peptidoglycan and is destined to develop into the cell wall of the outgrowing cell after spore germination.

Spore coat assembly is obvious at $\mathrm{T}=4.5 \mathrm{~h}$ (Fig. 20) and a thin, very dense line marks the rudiment of midcoat surrounding the outer forespore membrane (see below). In places, a second, outer concentric line of unknown function can also be seen. In this and subsequent figures, it seems that formation of this coat rudiment entraps undifferentiated cytoplasmic material in the region that later develops into the inner coat layer. At $\mathrm{T}=5 \mathrm{~h}$, approximately $50 \%$ of the cells have semirefractile forespores easily visible in the phase microscope (Table 1). The PCW and the initial coat layer are more easily visible (Fig. 21a) at this time, and the first signs of exosporium appear as a line of

Fig. 6. The final stage of vegetative cell division in B. sphaericus 9602. The cell termini have become rounded (arrow heads), and the protein layer is assembled on all parts of the separating cell ends. PG, peptidoglycan; bar $=0.25 \mu \mathrm{m}$.

Fig. 7. (a) Phase contrast micrograph of sporulating cells of B. sphaericus 9602 at $T=2 \mathrm{~h}$, showing sporulation septa (arrows). Bar $=10 \mu \mathrm{m} .(\mathrm{b})$ Nomarski interference micrograph of sporulating cells of $B$. sphaericus 9602 at $T=2 \mathrm{~h}$, showing sporulation septa and dimples (arrows) corresponding to sporulation septa at various stages of engulfment, as seen in thin-section electron micrographs. Bar $=10 \mu \mathrm{m}$.

Fig. 8. A. partially complete sporulation septum (arrows) in association with a large central mesosome $(M)$. $T=2 \mathrm{~h}$. The nuclear region is fibrillar and associated with a large vesicular mesosome. PG, peptidoglycan; bar $=0.25 \mu \mathrm{m}$. 

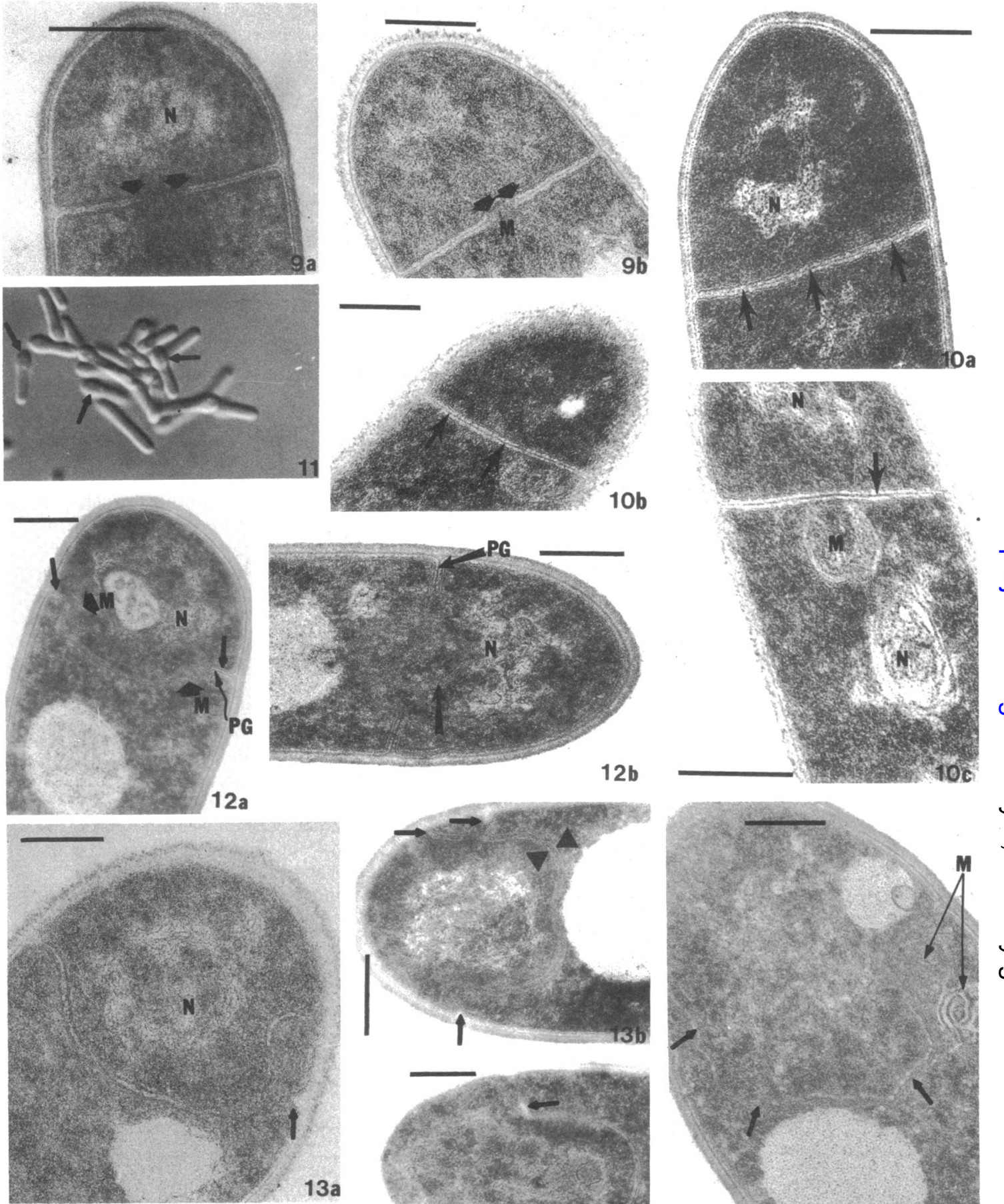

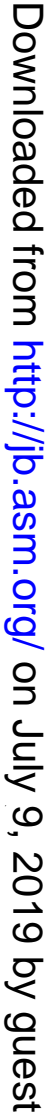

13a

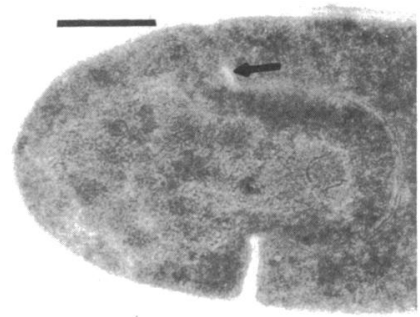

$13 \mathrm{c}$

Fig. 9. Final stages of sporulation septum completion in B. sphaericus $9602 . T=2 \mathrm{~h} ;$ bar $=0.25 \mu \mathrm{m}$. (a) An almost completed sporulation septum (arrows). (b) A completed sporulation septum associated with an ill-defined central mesosome (M). 
higher density immediately inside the mother cell cytoplasmic membrane opposite the midline of the developing spore.

In Fig. 21b, the lamellar midcoat appears to be surrounded by or perhaps to have been assembled inside of a thin, membranous layer of lower density. Nomarski interference (Fig. 22b) and phase contrast (Fig. 22a) micrographs taken at $\mathrm{T}=5$ to $5.5 \mathrm{~h}$ show semirefractile forespores. Electron micrographs of thin sections taken at this time give the clearest indication of differentiated layers between the inner forespore and the outer forespore membranes (Fig. 23). From inside out they are: (i) the PCW closely associated with the inner forespore membrane (the region of contact stains very darkly in places and has a particulate appearance); (ii) a region of low density that is developing cortex; and (iii) an external ring of higher density that may be the peptidoglycan layer first seen in Fig. 19. It is still visible in Fig. 24 and 25, but this layer and the forespore membranes are not clearly visible in mature and free spores (Fig. 27 through 34).

At $\mathrm{T}=6 \mathrm{~h}$ (Fig. 24), the cortex has become distended, the lamellar midcoat is almost continuous and outer coat and exosporium assembly are more advanced. These processes are further advanced at $\mathrm{T}=6.5 \mathrm{~h}$ (Fig. 25), when a much thicker cortex and a clearing or halo of almost transparent space outside the outer spore coat can also be seen. The inner coat region inside the lamellar midcoat now consists of a uniform matrix separated from the outer forespore membrane by a clearer zone. It no longer resembles trapped cytoplasm.

A transverse section through the midpoint of a forespore at $\mathrm{T}=6.5 \mathrm{~h}$ (Fig. 26) shows a highly organized outer coat resembling rows of circular, hollow, or tetragonally spiked subunits or particles about $5 \mathrm{~nm}$ in diameter. Inner fore- spore membrane and outer forespore membrane are barely visible, and the space between the outer forespore membrane and inner coat is no longer visible. The exosporium engulfs the forespore and the intervening space is cleared of polysomes except in one localized region. A longitudinal thin section taken at $\mathrm{T}=7 \mathrm{~h}$ (Fig. 27) shows extensive exosporium development. Its structure is complex at one point where it is advancing into the mother cell. Vegetative cell wall is still intact. By $\mathrm{T}=8 \mathrm{~h}$ distinct laminations in the developing exosporium and enlargement of the halo of cleared cytoplasm between it and the spore are apparent (Fig. 28).

At $\mathrm{T}=12 \mathrm{~h}$ (Fig. 29) an even larger halo surrounds the mature spore in a longitudinal thin section. The cell wall of the mother cell is still intact. Also seen at $\mathrm{T}=12 \mathrm{~h}$ is a mother cell, largely devoid of polysome granularity, which still surrounds a mature spore. The exosporium is complete with the outer lamella staining darker and thicker than the inner lamellae (Fig. 30).

Phase contrast (Fig. 31a) and Nomarski interference (Fig. 31b) micrographs at $\mathrm{T}=18 \mathrm{~h}$ show free spores with frequently visible thin, ghostlike exosporia resembling the mother cell in shape.

Free spores $(T=18 \mathrm{~h})$ are seen in thin section in Fig. 32 through 34a. In Fig. 33, the inner forespore membrane and PCW are indistinctly visible, and the inner spore coat is grainy and unstructured. However, up to five midcoat lamellae and outer coat layers are clearly visible. The outer coat is lamellar in some regions and is made up of distinct subunits with $5.6 \mathrm{~nm}$ separation in others. It is surrounded by a mass of fibrils. The exosporium also has up to five layers of variable staining density that is resolved in some regions into distinct subunits approx $6 \mathrm{~nm}$ apart. The cytoplasm of the spore

FIG. 10. Final stages of sporulation septum completion in B. sphaericus $9602 .(a, b$, and $c)$ Completed sporulation septa showing a continual line of the peptidoglycan layer (arrows). $T=2 h ; N$, condensed nuclear region; bar $=0.25 \mu \mathrm{m}$. (b) A peripheral or grazing section through a sporulation septum. (c) Note the close association between the sporulation septum with its continuous peptidoglycan (arrows), a vesicular mesosome $(M)$ and a fibrillar nucleoid $(N)$. Bar $=0.25 \mu \mathrm{m}$.

Fig. 11. Nomarski interference micrograph of $90 \%$ swollen cells at $T=2.2 \mathrm{~h}$. The arrows indicate the swollen vegetative cell terminus. Most cells have dimples marking engulfed forespores. Bar $=10 \mu \mathrm{m}$.

FIG. 12. ( $a$ and $b)$ Bulging or weakening of the softened center of a sporulation septum into the mother cell cytoplasm at $T=2.2 \mathrm{~h}$. The original septal stubs (arrows) are joined to the bulging septum by mesosome-like structures $(M)$. The peptidoglycan $(P G)$ is clearly seen within the septal stubs. $N$, nucleus; bar $=0.25 \mu m$.

FiG. 13. Early forespore engulfment in B. sphaericus 9602 at $T=2.2 h$. (a) Early forespore engulfment proceeds by detachment of the sporulation septum from one of its original points of initiation, visible as a residual stub (arrow). Bar $=0.25 \mu \mathrm{m}$. (b) In this section, engulfment by formation of double membranes (arrow heads) is proceeding at the right above the point at which the sporulation septum is still attached to its initiation point (arrows). Bar $=0.25 \mu \mathrm{m}$. (c) Part of the detached septum on the right (arrow) still seems to contain residual rigid (presumably peptidoglycan) material. The septum is still attached to one residual stub. Bar $=0.25 \mu \mathrm{m}$.

FIG. 14. A large peripheral mesosome $(M)$ associated with an engulfing forespore at $T=2.5 \mathrm{~h}$. The arrows outline the bulging forespore septum. Bar $=0.25 \mu \mathrm{m}$. 

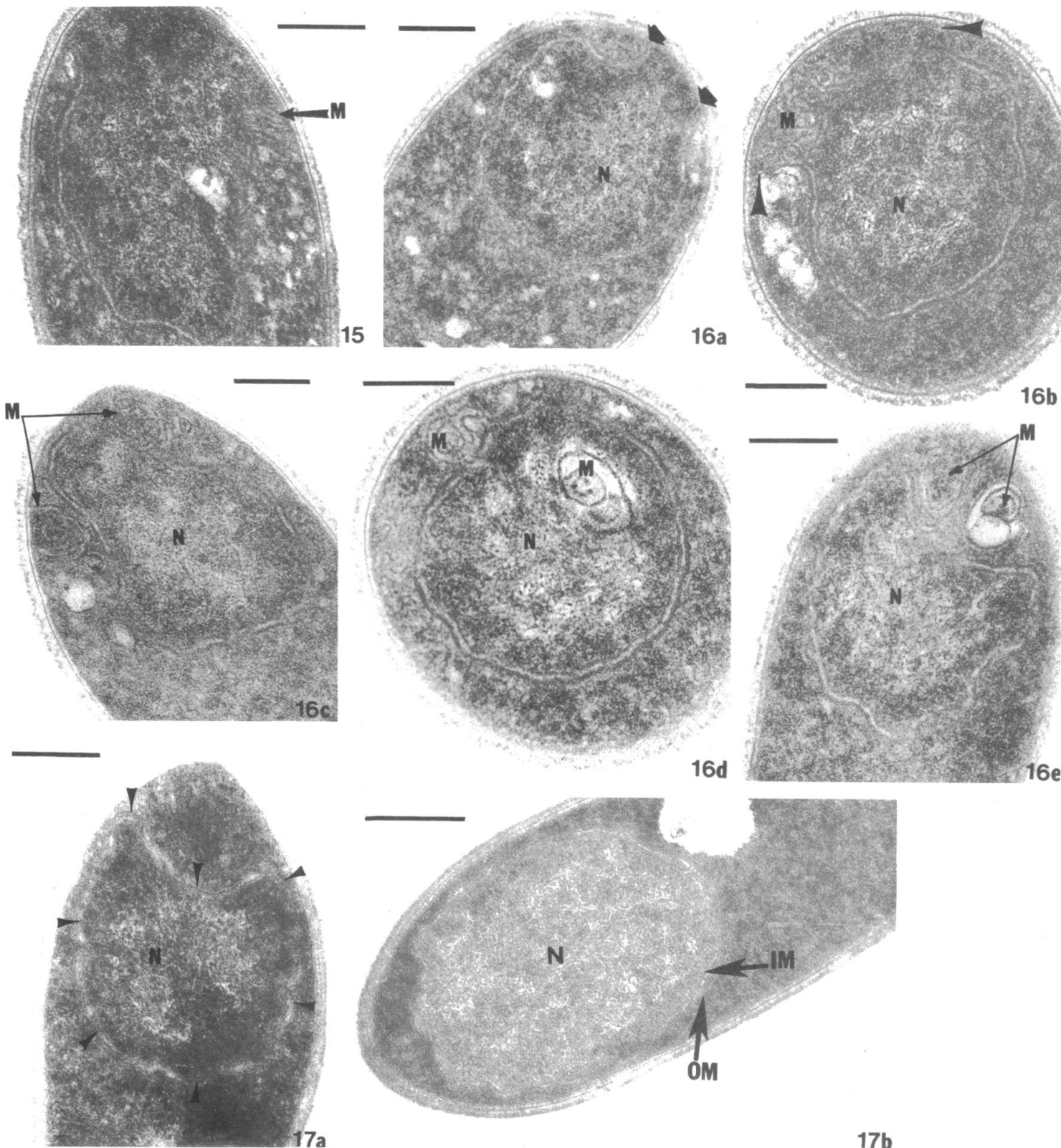

16d
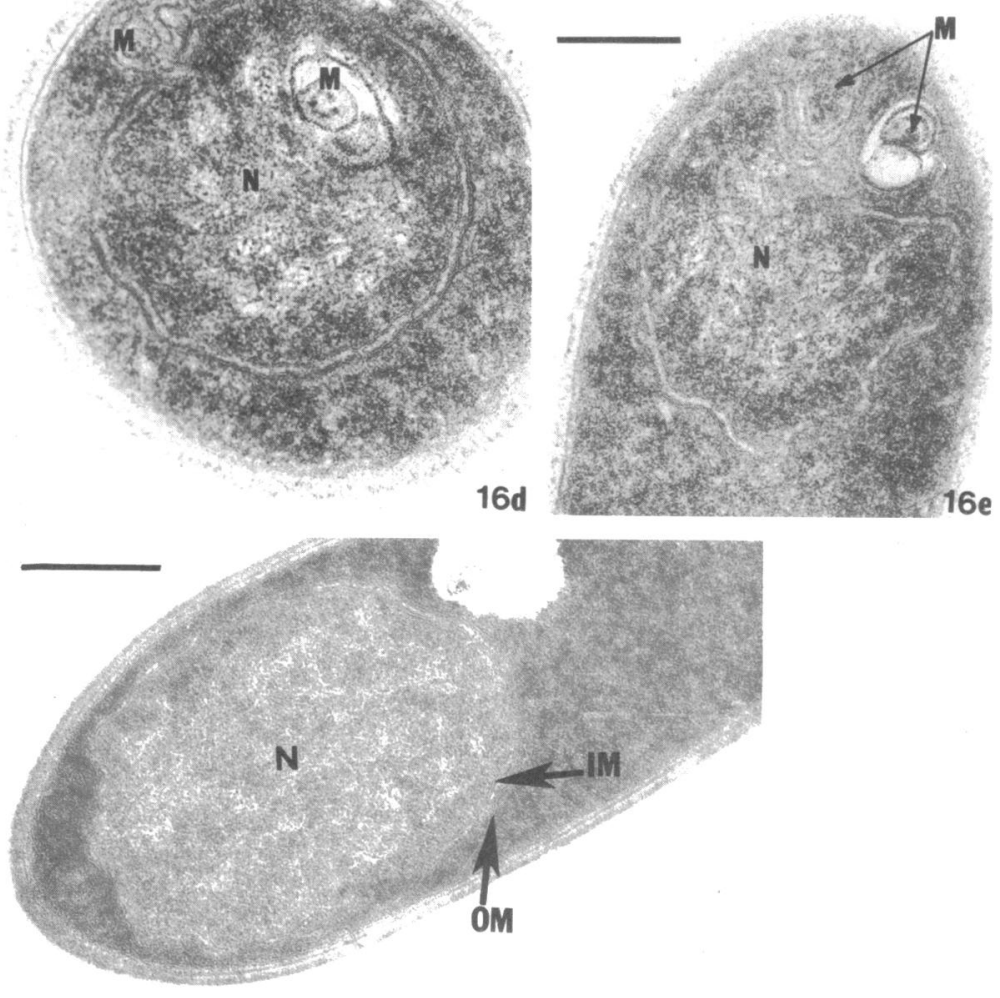

$17 \mathrm{~b}$

Fig. 15. A lamellar mesosome-like $(M)$ structure associated with one of the advancing edges in an engulfing forespore in B. sphaericus. $T=2.5 \mathrm{~h}$.

Fig. 16. Final stages in forespore engulfment in B. sphaericus. (a) An almost completely engulfed forespore at $T=3 \mathrm{~h}$. The arrouws indicate the attachment of the forespore membrane to plasma membrane. $N$, nucleus; bar $=0.25 \mu \mathrm{m} .(b$ and $c)$ Transverse sections through an almost completely engulfed forespore at $T=3 \mathrm{~h}$, showing considerable mesosome-like membranous material $(M)$ at the advancing edges of the membrane. Bar $=0.25 \mu \mathrm{m}$. (c and e) Longitudinal sections through almost completely engulfed forespores at $T=3 \mathrm{~h}$, showing accumulation of mesosome-like structures $(M)$ at the cell terminus. Bar $=0.25 \mu \mathrm{m}$.

Fig. 17. Longitudinal thin sections of $B$. sphaericus at $T=3.5 \mathrm{~h}$. (a) A fully engulfed nascent forespore. The arrows outline the forespore engulfment. Bar $=0.25 \mu \mathrm{m}$. (b) A nascent "prune-form" forespore with diffuse nucleoid $(N)$, plastic inner $(I M)$, and outer $(O M)$ forespore membranes. Bar $=0.25 \mu \mathrm{m}$. 
has the same large granules and light patches of condensed DNA seen in forespores at $\mathrm{T}=5.5 \mathrm{~h}$ (compare Fig. 21b).

The inner surface of the exosporium near its closed end has an array of subunits $12 \mathrm{~nm}$ apart (Fig. 32), and an oblique section through the closed end of the exosporium shows a hexagonal array of subunits of similar dimensions also at $12 \mathrm{~nm}$ separation, apparently on its inner surface (Fig. 34a). This is enlarged in Fig. 34b. The subunits are not consistently seen (compare Fig. 30 and 33), which is most probably the result of variation in the plane of cell sectioning.

\section{DISCUSSION}

The morphological stages of sporulation in gram-positive bacteria have been well documented by transmission electron microscopy of ultrathin sections of such aerobic organisms as $B$. subtilis, $B$. cereus, and $B$. megaterium. Similar studies have been performed with $\mathrm{Clos}$ tridium (reviewed in references 5,14 , and 25). The surface topography of the components of mother cell and spore envelopes has also been studied by freeze etching $(7,20)$ which demonstrated the architectural complexity of the spore coat layers. The general pattern of events that is seen in transmission electron microscopy is clear and always approximates the classical sequence of seven stages comprising: $I$, formation of an axial nucleoid filament; II, formation of the spore septum; III, engulfment of the forespore; IV, cortex synthesis; V, coat synthesis; VI, maturation, that is, dehydration, accumulation of dipicolinic acid and calcium and acquirement of ultraviolet and heat resistance; and VII, release of the free, mature spore. The events which occur during stages IV to VII are at least partially dissociable from one another, that is, free spores are not always produced, and the events of cortex and spore coat synthesis are not necessarily sequential. Some evidence indicates that, in $B$. cereus $T$ for example, synthesis of spore coat precursors occurs very early in sporulation, long before the appearance of any cortex (1).

Whereas spores of some aerobic spore formers such as $B$. subtilis lack any loosely associated external envelope, spores of other species such as $B$. cereus have a well-developed exosporium, as do many clostridia (compare reference 20). In $B$. cereus, assembly of the exosporium is initiated close to the outer forespore membrane at the internal pole of the forespore prior to the initiation of spore coat development and at a time when very little cortex is present (17). As the exosporium develops around the forespore, the spore coat appears as an equatorial band which is not wholly enclosed by the exosporium.
Murrell has pointed out that the lamellar midcoat layer is the first to appear, and its formation apparently entraps mother cell cytoplasmic material in the region which later becomes the inner spore coat. It is by no means clear whether the spore coat is derived by modification or displacement of this mother cell cytoplasm. Exosporia in clostridia have been divided into three morphological classes (10) and development of the lamellar variety appears to proceed quite differently. For example, in Clostridium botulinum 78A (21), the first assembled layer of what will become exosporium is seen closely adjacent to the mother cell plasma membrane at a point surrounding the forespore at the same time as the first signs of spore coat formation are visible and before there is visible cortex present.

The sequence of sporulation events in $B$. sphaericus revealed by electron microscopy is fairly typical, except for the terminal swelling. Formation of a sporulation septum is followed after $30 \mathrm{~min}$ by engulfment of the forespore concomitantly with swelling. As peptidoglycan (probably primordial cell wall) appears between the forespore membranes, midcoat development commences. As this develops into distinct lamellae, cortex, outer coat, and exosporium development begin and all layers mature simultaneously, ending in the following sequence: PCW, cortex and coats, and finally exosporium. The location of development of the exosporium is like that of $C$. botulinum 78A (21). Gerhardt and Ribi (6) reported that the inner surface of $B$. cereus exosporium is laminated and appears as a hexagonal lattice in surface view. The $B$. sphaericus exosporium may be similar, although its hexagonal array of subunits (Fig. $34 \mathrm{~b})$ seem to be underneath the lamellar layers. One layer of $C$. sporogenes exosporium also has a hexagonal pattern of subunits (20).

This sequence of events visualized during sporulation in $B$. sphaericus is summarized in Fig. 1 and Table 1 . The cell wall profile of $B$. sphaericus strain P1 (12), like that of strain 9602 , consists of a thick outer and a thin inner dense layer separated by a nonstaining layer (Howard, Holt, and Tipper, unpublished observations). Several phage-resistant mutants of strain P1 have a T-layer made up of protein of reduced molecular weight (12) and have a loosely organized, incomplete outer densely staining layer. Moreover, treatment of wildtype cell walls of $B$. sphaericus strain $\mathrm{P} 1$ and 9602 with $6 \mathrm{M}$ urea removes $95 \%$ of the T-layer protein and completely removes the outer densely staining layer from intact cells (Holt, Howard, and Tipper, unpublished observations). Thus, the outer densely staining layer 

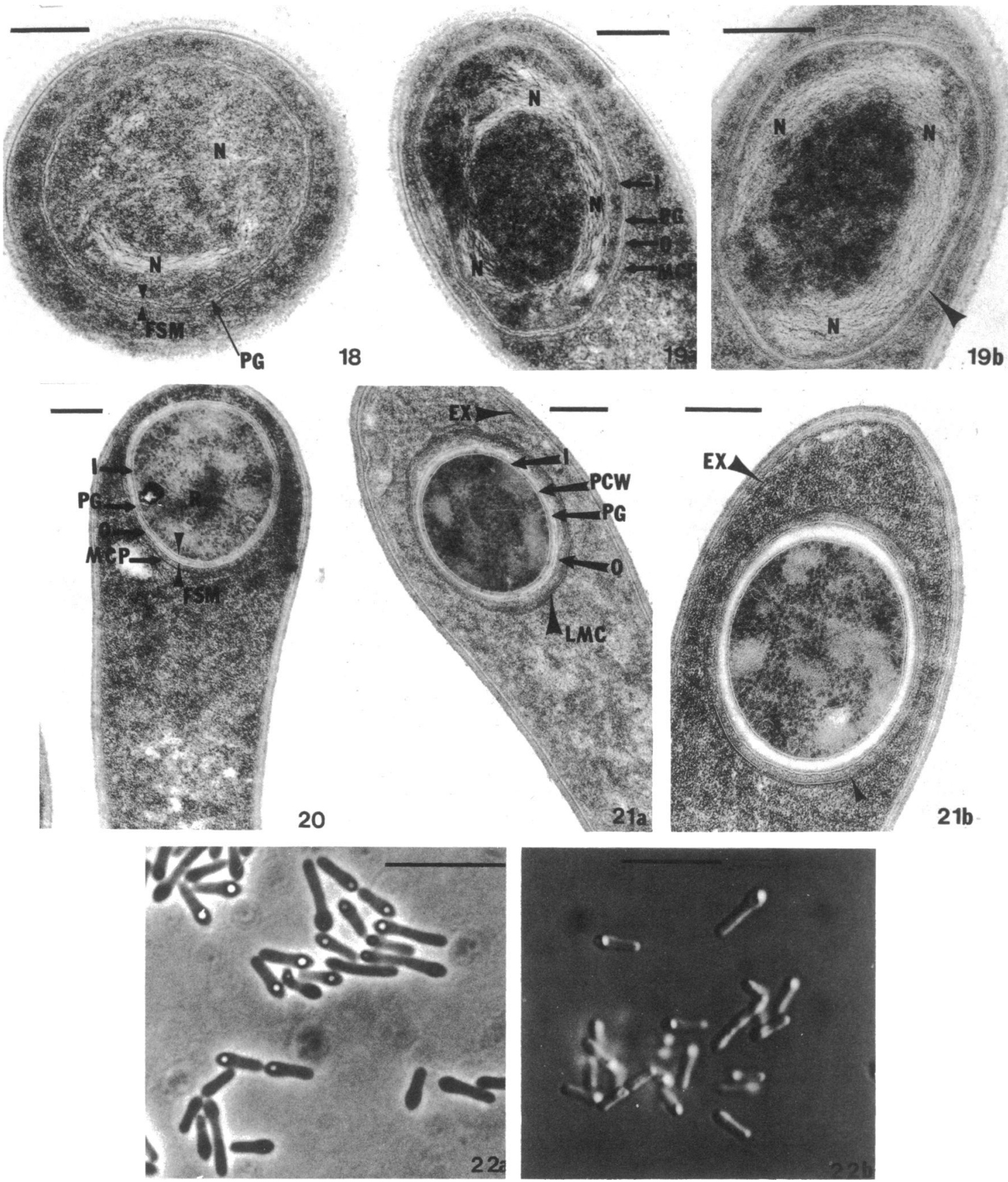

$21 b$

Fig. 18. Transverse section of a forespore of $B$. sphaericus in which the nucleoid $(N)$ is partially condensed into a fibrillar form and a thin layer, presumed to be peptidoglycan $(P G)$, is visible between the circumferential forespore membranes which have adopted a rounded configuration (FSM). T=4 h; bar $=0.25 \mu \mathrm{m}$.

Fig. 19. ( $a$ and $b)$ Forespores of B. sphaericus showing fully condensed fibrillar nucleoids $(N)$ and rounded shape with peptidoglycan $(P G)$ between the forespore membranes and the first signs of organized spore coat. I, $O=$ inner and outer forespore membrane, respectively; $M C P$, midcoat precursor. $T=4 h ; b a r=0.25 \mu m$.

Fig. 20. Forespore of B. sphaericus with a mature-appearing cytoplasm completely surrounded by mid-coat precursor $(M C P)$. The peptidoglycan layer $(P G)$ is still symmetrically located between the inner $(I)$ and outer (O) forespore membranes. $R$, ribosome clusters. $T=4.5 \mathrm{~h} ;$ bar $=0.25 \mu \mathrm{m}$. 
seen in thin sections corresponds to the T-layer protein of the cell wall.

Treatment of intact cells of strains P1 and 9602 with lysozyme in the presence of sucrose as an osmotic stabilizer leads to fragmentation and eventual disappearance of the inner dense layer of the cell wall, leaving the outer T-layer intact (Howard, Holt, and Tipper, unpublished observations). Thus, the inner dense layer is either peptidoglycan or a cell wall component whose integrity, unlike that of the T-layer, is dependent upon the integrity of the peptidoglycan and is susceptible to the action of lysozyme. The former possibility is the most consistent with observations made on the cell walls of other gram-positive species (compare reference 15). The nature and relationship of the inner light layer of the cell wall to the inner dense layer are unclear. However, in plasmolyzed cells of strain P1, no inner boundary for the inner light layer is seen, leading to speculation that this layer may simply be "periplasmic space" between the peptidoglycan, that is, the inner dense layer, and the plasma membrane.

Spore septum formation results in the formation of a planar, apparently rigid septum (Fig. $10 \mathrm{a}, \mathrm{b})$ resembling closely a newly completed vegetative cross wall (Fig. 4). However, it does not mature by duplication of the peptidoglycan layer and cell separation, but rather the single peptidoglycan layer disappears from the center outwards, at the time of swelling. Such disappearance is presumably a result of autolysis by localized action of peptidoglycan hydrolases (autolysins), and the same autolysins may catalyze remodeling of the vegetative cell symmetrically around the periphery of the spore septum to form the swollen end that is bisected by that septum. As reported by Hitchins and Slepecky (9) for B. cereus $T$, inhibitors of peptidoglycan synthesis such as vancomycin inhibit spore septum formation in $B$. sphaericus. When added at $\mathrm{T}=1.5 \mathrm{~h}$, no terminal swelling ensues. When added at $\mathrm{T}=2 \mathrm{~h}$, partially swollen cells proceed to swell fully and produce nonrefractile spores (Khachatourians and Tipper, unpublished observations). This may implicate peptidoglycan synthesis in septation and swelling during sporulation and substantiates the hypothesis (8) that the early stages of sporulation are an abnormal cell division. "Commitment" to sporulation, even in the presence of fresh medium, occurs in B. sphaericus at the time of initiation of swelling (24), perhaps when the normal cell division process is irreversibly interrupted by autolysis of the nascent cross wall. It remains to be determined whether similar events occur in spore septum formation in all bacilli. It may be more economical to maximize the use of vegetative cell division machinery during sporulation and in bacilli septal membrane and cross wall synthesis may be interdependent. It is also possible that the cross wall (vegetative-type) peptidoglycan is not completely degraded and that some of it persists adjacent to the forespore membrane where it acts as acceptor for germ cell wall and cortex synthesis.

It has been demonstrated by Fitz-James (4) that if sporulating cells of $B$. cereus which have formed a sporulation septum are transferred to fresh medium, the septum develops into a cross wall and both parts of the cell will eventually develop into vegetative cells. Moreover, mutants of $B$. subtilis blocked at stage II, on continued incubation under sporuation conditions, form thick cross walls within the sporulation septa (3). Similar results were reported by Ryter et al. (18) and Balassa and Yamamoto (2); asymetrical cross walls are also produced by cells of a $B$. subtilis mutant which accumulates L- $\alpha$-glycerophosphate (16). Thus, cross wall formation in sporulation septa occurs under abnormal conditions in several bacilli, indicating the presence of the necessary peptidoglycan synthesizing machinery. In $B$. sphaericus the functioning of this machinery is obvious under ordinary conditions. Perhaps this occurs transiently in all bacilli, but is abnormally visible in $B$. sphaericus due to its weak autolytic capacity.

The sequence of events involved in forespore engulfment is diagrammed in Fig. 35, which consists of tracings of the indicated thin sections, with emphasis on the membranes and the cell wall layers. From the initial central bulging of the septum into the mother cell cytoplasm

Fig. 21. (a) In this forespore of B. sphaericus, the primordial cell wall (PCW) has attained almost its full thickness and is separated from the original thin peptidoglycan layer $(P G)$, which remains adjacent to the outer forespore membrane $(O)$, by a slightly widened region of low electron density. This region presumably indicates the initiation of cortex synthesis. Lamellar organization of the midcoat (LMC) is well advanced, and rudimentary exosporium $(E X)$ is forming adjacent to the mother cell cytoplasmic membrane surrounding the forespore. $T=5 \mathrm{~h}$; bar $=0.25 \mu \mathrm{m}$. (b) A thin, membrane-like layer can be seen in some places immediately outside of the site of assembly of the lamellar midcoat (arrow). Again, a rudiment of exosporium (EX) is visible. $T=5 \mathrm{~h} ; \mathrm{bar}=0.25 \mu \mathrm{m}$.

Fig. 22. (a) Phase contrast micrograph of B. sphaericus cells with $60 \%$ semirefractile forespores at.T=5 $h$. Bar $=10 \mu \mathrm{m}$. (b) Nomarski interference micrograph of $B$. sphaericus cells with $80 \%$ semirefractile forespores at $T=5.3 \mathrm{~h} . \mathrm{Bar}=10 \mu \mathrm{m}$. 

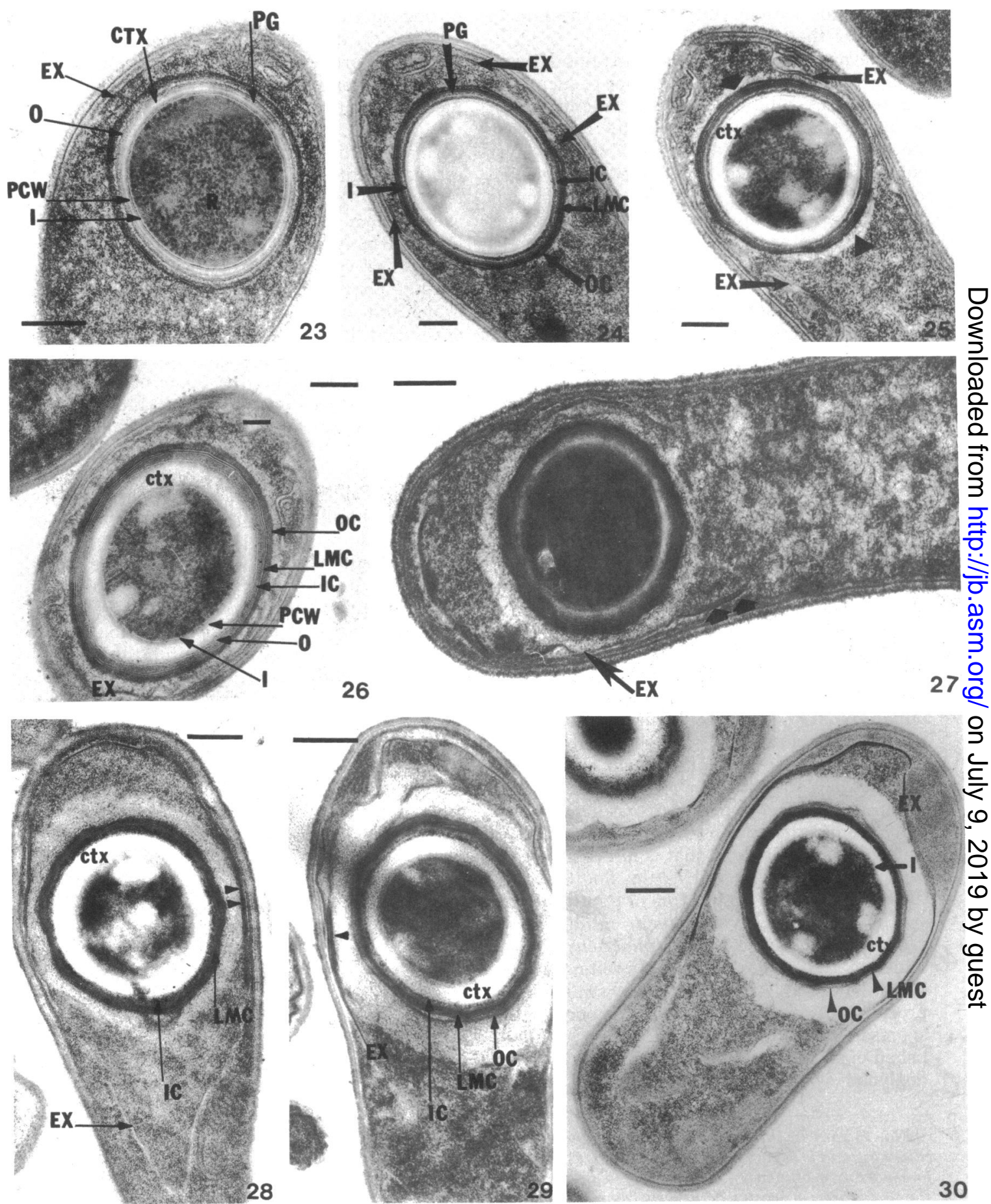
(Fig. 35B) to the end of engulfment (Fig. 35K), the two membranes destined to surround the forespore are plastic and have no visible structure separating them. Engulfment proceeds by separation of the septum from its vestigial peptidoglycan stub (Fig. 35D, E, F). According to a plausible model describing the topography of new membrane synthesis during engulfment of the forespore (compare reference 23), the outer forespore membrane comprises the inward half of the spore septum membrane, plus fresh components intercalated at the advancing edge of engulfment. These fresh components may be unique and not present in the vegetative cell or the inner forespore membrane and have functions in cortex and coat synthesis.

This model suggests that the inner forespore membrane consists of the outer half of the spore septum plus the original plasma membrane of the mother cell terminus. This derivation would be consistent with its role in the synthesis of a primordial cell wall of vegetative peptidoglycan. In this model the plasma membrane of this mother cell terminus must also be replaced during engulfment and so may be identical to most of the outer forespore membrane. It is then hard to understand how the outer forespore membrane and not the adjacent mother cell plasma membrane can direct the elaboration of cortex and the assembly of sporecoats. This process is diagrammed in the series of profiles shown in Fig. $35 \mathrm{M}$ to $\mathrm{S}$ (note the differences in magnification).

A line of what may be peptidoglycan appears between the two membranes of the forespore at $T=4 \mathrm{~h}$, shortly after engulfment is complete (Fig. 35L, N, O), and migrates out- ward with the outer forespore membrane as first PCW (Fig. 35P) and then cortex (Fig. 35Q, R, S) appears between it and the inner forespore membrane. It is not clearly visible in mature spores. PCW development seems to be complete between $\mathrm{T}=5 \mathrm{~h}$ and $\mathrm{T}=6 \mathrm{~h}$ and cortex only by $\mathrm{T}=7 \mathrm{~h}$. The first sign of coat development is also seen at $\mathrm{T}=4 \mathrm{~h}$ (Fig. $35 \mathrm{~L}, \mathrm{~N}, \mathrm{O}$ ) and appears to be a precursor of the lamellar midcoat, either a matrix within which the coat assembles, or incompletely assembled midcoat. No obvious membrane separates it from the mother cell cytoplasm. The completion of coat assembly is shown in the remaining profiles (Fig. 35P, Q, R, S).

Freeze etching $(8,20)$ has shown outer spore coats to have large patches of parallel rows or arrays of subunits, randomly arranged with respect to each other. A cross-section might show distinct subunits (apparently hollow circles) (Fig. 26 and 35S), whereas a longitudinal section might look more like lamellae (Fig. 33). In contrast, the midcoat lamellae continuously surround the spore in section, so are presumably derived from continuous concentric shells of heavily stained and unstained layers.

Exosporium is seen only indistinctly, even at $\mathrm{T}=6 \mathrm{~h}$, and achieves a fully lamellar organization only by $\mathrm{T}=8 \mathrm{~h}$. Its assembly appears to be directed by the mother cell plasma membrane and commences adjacent to the center of the forespore. Again it is hard to understand how the mother cell and outer forespore membranes gain their different functions, one controlling coat and the other controlling exosporium assembly. The exosporium has some resemblance to outer coat, although it lacks the hairy mass of

Fig. 23. Primordial cell wall (PCW) adjacent to the inner forespore membrane is clearly distinguished by its higher density of staining from a surrounding lighter zone of cortex $(C T X) . T=5.5 \mathrm{~h}$; bar $=0.25 \mu \mathrm{m}$.

Fig. 24. This forespore of $B$. sphaericus has an essentially continuous lamellar midcoat $(L M C)$ which is already surrounded by one or two membranous arrays of outer coat subunits (OC). Exosporium (EX) development is now much more obvious. $T=6 \mathrm{~h} ;$ bar $=0.25 \mu \mathrm{m}$.

Fig. 25. Exosporium and outer coat development is more advanced and the cortex (CTX) surrounding the primordial cell wall is already thick. Surrounding the outer spore coat is a halo (arrow heads) of low-staining density where a hairy, fibrillar material is displacing the granular mother cell cytoplasm. $T=6.5 \mathrm{~h} ; \mathrm{bar}=0.25$ $\mu \boldsymbol{m}$.

Fig. 26. This spore of B. sphaericus has a well-developed cortex (CTX) surrounding a clearly visible primordial cell wall (PCW). It has a diffuse inner coat (IC) which no longer resembles mother cell cytoplasm, one or two lamellae of midcoat $(L M C)$, and a highly organized outer coat $(O C)$. Both inner $(I)$ and outer $(O)$ forespore membranes are still distinguishable. $T=6.5 \mathrm{~h} ; \mathrm{bar}=0.25 \mu \mathrm{m}$.

Fig. 27. Expansion of the halo surrounding the spore coats to the point where it reaches the developing exosporium (EX) renders the exosporium more clearly visible. At one point where the exosporium is advancing into the mother cell cytoplasm, it has an inner particulate layer (arrow heads). $T=7 \mathrm{~h} ;$ bar $=0.25 \mu \mathrm{m}$.

Fig. 28. Parts of the exosporium which lie closest to the spore have a lamellar structure (arrow heads). The inner coat (IC), cortex (CTX), and lamellar midcoat (LMC) are visible. $T=8 \mathrm{~h} ;$ bar $=0.25 \mu \mathrm{m}$.

FIG. 29. This longitudinal section of a B. sphaericus cell containing a mature spore shows that the clearing of the mother cell cytoplasm now extends to most of the space between the outer coats and the exosporium, which again shows lamellae (arrow) at the point of closest approach to the spore. $T=12 \mathrm{~h}$; bar $=0.25 \mu \mathrm{m}$.

Fig. 30. The lamellar exosporium in this cell has a dark staining outer layer and lighter staining inner layers. $T=12 \mathrm{~h} ; \mathrm{bar}=0.25 \mu \mathrm{m}$. 




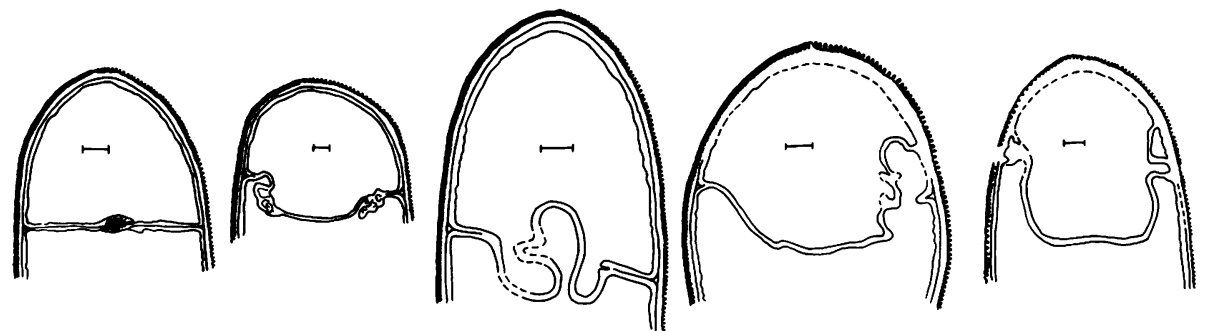

A

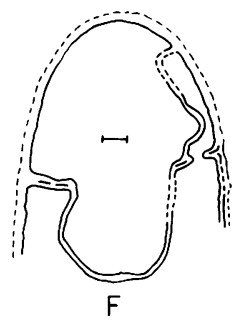

F

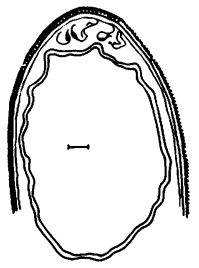

K
B

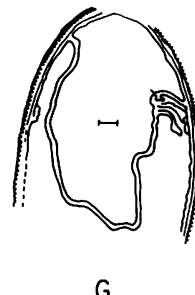

C

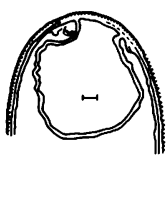

H
D
$E$

Fig. 31. (a) Phase contrast micrograph of free spores of $B$. sphaericus showing exosporia (arrows). $T=18 \mathrm{~h}$; bar $=10 \mu \mathrm{m}$. (b) Nomarski interference micrograph of free spores showing a faint exosporium (arrows). $T=18$ $h ; b a r=10 \mu \mathrm{m}$.

Fig. 32. A free spore of $B$. sphaericus with a longitudinal section of the exosporium which approximately retains the shape of the mother cell. The spore is surrounded by a fuzzy mass of fibrils (arrow), and the inner surface of the lamellar exosporium has subunits (arrow heads) at a separation of $12 \mathrm{~nm} . T=18 \mathrm{~h} ;$ bar $=0.25$ $\mu \mathrm{m}$.

Fig. 33. This spore of $B$. sphaericus has up to five lamellar layers of midcoat (LMC), outer coat (OC), and exosporium $(E X)$. In some cases the exosporium, like the outer coat, appears to be made up of rows of subunits at approximately $6 \mathrm{~nm}$ separation (arrows). The inner coat (IC) is granular and the outer forespore membrane cannot be distinguished. However, the inner forespore membrane and primordial cell wall are indistinctly visible. $T=18 \mathrm{~h} ;$ bar $=0.25 \mu \mathrm{m}$.

Fig. 34. (a) A free spore of $E$. sphaericus. A glancing section through the terminal portion of the exosporium revealing the presence of hexagonally arranged subunits on its inner surface. Bar $=0.25 \mu m$. (b) Enlargement of this portion of the exosporium. Bar $=0.1 \mu \mathrm{m}$. 
fibrils that appear to be attached to the outer spore coat. These fibrils may be unassembled coat subunits. They displace polysomes from the periphery of the developing spore, producing a "halo" which is first seen at $\mathrm{T}=6.5 \mathrm{~h}$ (Fig. 25).

Biochemically defined events during $B$. sphaericus sporulation include turnoff of synthesis of all enzymes involved in peptidoglycan precursor synthesis (other than alanine racemase) at $\mathrm{T}=$ $0 \mathrm{~h}$, and their derepression at $\mathrm{T}=3$ to $4 \mathrm{~h}$, followed shortly (at $\mathrm{T}=4.5 \mathrm{~h}$ ) by synthesis of the meso-diaminopimelate ligase which is uniquely found in sporulating cells (24). The latter event occurs just in advance of visible PCW and cortex synthesis at $\mathrm{T}=4.5 \mathrm{~h}$ (Table 1). Dipicolinate synthesis starts at about $T=$ $5.5 \mathrm{~h}$ and is maximal at $\mathrm{T}=6.5 \mathrm{~h}$, when spores are becoming phase bright. The transcriptional and translational machinery of the cell must be functional at these late times $(T=4.5$ to $6.5 \mathrm{~h})$ since the appropriate inhibitors prevent accumulation of diaminopimelate ligase and dipicolinate (24). It seems unlikely that the forespore machinery is functional after $\mathrm{T}=4 \mathrm{~h}$ when it becomes spore-like, and it is most probable that the mother cell cytoplasm is responsible for these differential functions. This hypothesis is borne out by analysis of enzyme activities in the mother cell and forespore fractions (Tipper and Linnett, unpublished observations).

\section{ACKNOWLEDGMENTS}

This study was supported by Public Health Service grant AI10806 from the National Institute of Allergy and Infectious Diseases.

We thank Erika Musante for her excellent technical assistance.

\section{LITERATURE CITED}

1. Aronson, A. I., and P. C. Fitz-James. 1968. Biosynthesis of bacterial spore coats. J. Mol. Biol. 33:199-212.

2. Balassa, G., and T. Yamamoto. 1970. Biochemical genetics of bacterial sporulation. III. Correlation between morphological and biochemical properties of sporulation mutants. Mol. Gen. Genet. 108:1-22.

3. Coote, J. G., and J. Mandelstam. 1973. Use of constructed double mutants for determining the temporal order of expression of sporulation genes in Bacillus subtilis. J. Bacteriol. 114:1254-1263.

4. Fitz-James, P. C. 1963. Spore formation in wild and mutant strains of $B$. cereus and some effects of inhibitors, p. 529-544. In Mechanismes de regulation des activites cellulaires chez les microorganisms. Chrs. Colloq. Intern. Centre Nat. Rech. Sci., no. 124.

5. Fitz-James, P. C., and I. E. Young. 1969. Morphology of sporulation, p. 39-72. In G. W. Gould and A. Hurst (ed.), The bacterial spore. Academic Press Inc., London.

6. Gerhardt, P., and E. Ribi. 1964. Ultrastructure of the exosporium enveloping spores of Bacillus cereus. J. Bacteriol. 88:1774-1789.
7. Greene, R. A., S. C. Holt, E. R. Leadbetter, and R. A. Slepecky. 1971. Correlation of light and electron microscopic observations of sporulation in Bacillus megaterium, p. 161-174. In A. N. Barker, G. W. Gould, and J. Wolf (ed.), Spore research 1971. Academic Press Inc., London.

8. Hitchins, A. D., and R. A. Slepecky. 1969. Bacterial sporulation as a modified procaryotic cell division. Nature (London) 223:804-807.

9. Hitchins, A. D., and R. A. Slepecky. 1969. Antibiotic inhibition of the septation stage in sporulation in Bacillus megaterium. J. Bacteriol. 97:1513-1515.

10. Hodgkiss, W., Z. J. Ordal, and D. C. Cann. 1967. The morphology and ultrastructure of the spore and exosporium of some Clostridium species. J. Gen. Microbiol. 47:213-225.

11. Holt, S. C., and E. R. Leadbetter. 1969. Comparative ultrastructure of selected aerobic spore-forming bacteria: a freeze-etching study. Bacteriol. Rev. 33:346-378.

12. Howard, L., and D. J. Tipper. 1973. A polypeptide bacteriophage receptor: modified cell wall protein subunits in bacteriophage-resistant mutants of Bacillus sphaericus strain P-1. J. Bacteriol. 113:1491-1504.

13. Hungerer, K. D., and D. J. Tipper. 1969. Cell wall polymers of Bacillus sphaericus $\mathbf{9 6 0 2}$. I. Structure of the vegetative cell wall peptidoglycan. Biochemistry 8:3577-3587.

14. Murrell, W. G., D. F. Ohye, and R. A. Gordon. 1971. Cytological and chemical structure of the spore, p. 1-19. In L. L. Campbell (ed.), Spores IV. American Society for Microbiology, Bethesda, Md.

15. Nermut, M. V., and R. G. E. Murray. 1967. Ultrastructure of the cell wall of Bacillus polymyxa. J. Bacteriol. 93:1949-1965.

16. Oh, Y. K., E. B. Freese, and E. Freese. 1973. Abnormal septation and inhibition of sporulation by accumulation of L- $\alpha$-glycerophosphate in Bacillus subtilis mutants. J. Bacteriol. 113:1034-1045.

17. Ohye, D. F., and W. G. Murrell. 1973. Exosporium and spore coat formation in Bacillus cereus T. J. Bacteriol. 115:1179-1190.

18. Ryter, A., P. Schaeffer, and H. Ionesco. 1966. Classification cytologique, par leur stade de blocage, des mutants de sporulation de Bacillus subtilis Marburg. Ann. Inst. Pasteur (Paris) 119:305-315.

19. Schleifer, K. H., and O. Kandler. 1972. Peptidoglycan types of bacterial cell walls and their taxonomic implications. Bacteriol. Rev. 36:447-477.

20. Short, J., and P. D. Walker. 1971. Structure of bacterial spores as revealed by freeze etching, p. 189-192. In A. N. Barker, G. W. Gould, and J. Wolf (ed.), Spore research 1971. Academic Press Inc., London.

21. Stevenson, K. E., and R. H. Vaughan. 1972. Exosporium formation in sporulating cells of Clostridium botulinum 78A. J. Bacteriol. 112:618-621.

22. Tipper, D. J. 1973. Bacterial cell walls, p. 121-205 and 331-346. In S. Timasheff and G. Fasman (ed.), Biological macromolecules, vol. 6B. Marcel Dekker, New York.

23. Tipper, D. J., and J. J. Gauthier. 1972. Structure of the bacterial endospore, p. 3-12. In $\mathbf{H}$. O. Halvorson, $\mathbf{R}$. Hanson, and L. L. Campbell (ed.), Spores V. American Society for Microbiology, Washington, D.C.

24. Tipper, D. J., and I. Pratt. 1970. Cell wall polymers of Bacillus sphaericus 9602 . II. Synthesis of the first enzyme unique to cortex synthesis during sporulation. J. Bacteriol. 103:305-317.

25. Walker, P. D. 1970 . Cytology of spore formation and germination. J. Appl. Bacteriol. 33:1-12.

26. Warth, A. D., and J. L. Strominger. 1972. Structure of the peptidoglycan from spores of Bacillus subtilis. Biochemistry 11:1389-1395. 